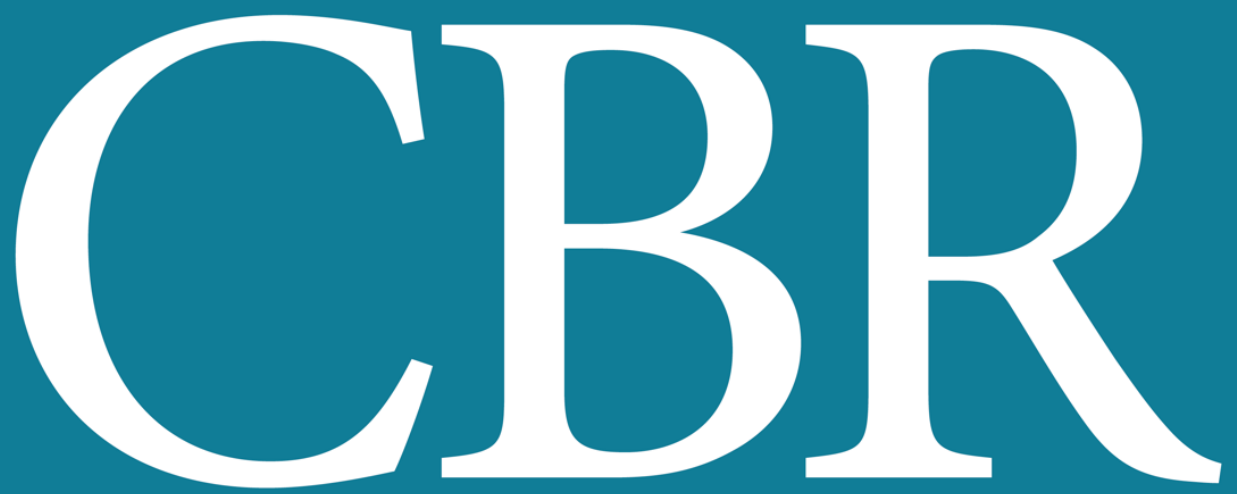

INTERNATIONAL JOURNAL OF CANCER AND BIOMEDICAL RESEARCH

https://jcbr.journals.ekb.eg

Editor-in-chief

Prof. Mohamed Labib Salem, PhD

The mystery behind Childhood sparing by COVID-19

Samar Salman, Mohamed Labib Salem 


\section{International Journal of Cancer \& Biomedical Research \\ (IJCBR) https://jcbr.journals.ekb.eg}

IJCBR is an Int. journal published by the Egyptian Society of Cancer Research (EACR, established in 2014, http://eacr.tanta.edu.eg) and sponsored by the Egyptian Knowledge Bank (EKB: www.ekb.eg).

IJCBR has been approved by the Supreme Council of Universities, Egypt with score 7 (http://egjournal.scu.eg). The journl is cited by google scholar and registered by Publons (https://publons.com). The journal has recently been evaluated in 2020 by Nature Springer with a good standing.

\section{Scope of IJCBR}

- Drug discovery from natural and synthetic resources

- BioMedical applications of nanotehnology

- Sem cell biology and its application

- Basic and applied biotechnology

- Inflammation and autoimmune diseases

- In slico models and bioinformatics

- In vitro and In vivo preclinical animal models

- Cellular and molecular cancer biology

- Cancer Immunology and Immunotherapy

- New methods for prediction, early detection, diagnosis prognosis and treatment of dieases.

- Immunology in health and dieases

- Anti-microbial defense mechanisms

- Cellular and molecular physhiology and pahthology of diseases

\section{IJCBR Editor,}

Prof. Mohamed Labib Salem, PhD

Professor of Immunology

Faculty of Science, Tanta Universiy, Egypt 


\title{
The mystery behind Childhood sparing by COVID-19
}

\author{
Samar Salman ${ }^{1}$, Mohamed Labib Salem ${ }^{2}$ \\ ${ }^{1}$ Department of Dermatology and Venereology, Tanta University Hospital, Faculty of Medicine \\ 2Zoology Department, Faculty of Science; Tanta University Teaching Hospital Tanta University, Tanta, Egypt
}

\section{IIII}

In December 2019, the SARS-CoV-2 virus was firstly emerged in Wuhan, China and then spread rapidly worldwide to be declared as a pandemic by the World Health Organization (WHO) in March 2020. COVID-19, the threatening acute respiratory distress disease caused by SARS-CoV-2 virus, showed preferential age groups selection (1).

Data regarding the epidemiologic and clinical features of infected children showed that out of 72,314 cases, recorded by the Chinese Center for Disease Control and Prevention, only less than $1 \%$ of the cases were pediatrics younger than 10 years of age and in contrary with the infected adults, most infected children seemed to have a milder clinical course. Also, asymptomatic infections were not uncommon (2).

We suppose that the global routine immunization of children could play a role in protection of the pediatric age form the devastating effect of SARS-CoV-2. MMR, BCG, PPD, and Candida vaccines are already used as treatment options enhancing the ability of the immune system to recognize certain viral antigens (3). For example, in dermatology, verruca that is caused by human papilloma virus can be ameliorated using these above mentioned intralesional vaccinations (4). As reported, COVID-19 patients are manifested by lymphopenia and decreases in the numbers of cytotoxic CD8+ T cells (5). According to our hypothesis, this induced leukopenia could be corrected by these mentioned vaccinations. This correction when happens will accordingly stimulate CD4+ helper $T$ helper 1 cells and induce them to secrete various cytokines provoking the maturation of cytotoxic CD8+ T cell. This scenario is expected to also improve the cytotoxic capabilities of natural killer (NK) cells. Both those types of cytotoxic cells (CD8+ and NK cells) can then recognize and destroy virus-infected cells (6).

The data from China showed that also that pediatric patients less than one year old suffer from severe to critical symptoms while older children are manifested with less symptoms (7). Given that MMR is given after one year (8), this lower severity of the symptoms in children over 1 year could be an indicator for the beneficial role of vaccinations. It could also be a proof against the hypothesis stating that lower immunity in children, because of their imperfect innate immune development (9), dose not exaggerate the immune response against the virus as adults do. Furthermore, in a randomized clinical trial BCG (bacillus Calmette-Guérin) vaccination has been found to induce protection against infection with a weakened form of the yellow fever virus $(10,11)$. Review reports by the WHO in 2014 and 2016 also concluded that BCG vaccination associates with lower overall mortality in children. In support to our opinion, the results of a recent case study (12) indicated that robust multi-factorial immune responses can be induced against SARS-CoV-2 similar to those found in response to the avian H7N9 disease (13).

Overall, we suggest that the bystander immunity induced after vaccination of children from 1-8 years old can stimulate the immunity against SARS-CoV-2 virus. Therefore, we recommend assessing the use of one or combined vaccination of MMR, BCG, PPD, and Candida to either protect the high-risk groups or to treat the emerging pandemic of SARS- CoV-2 virus and the associated serious complication of COVID-19 as we have recently proposed that routine childhood immunization may protect against COVID-19 (14).

\section{ARTICLE INFO}

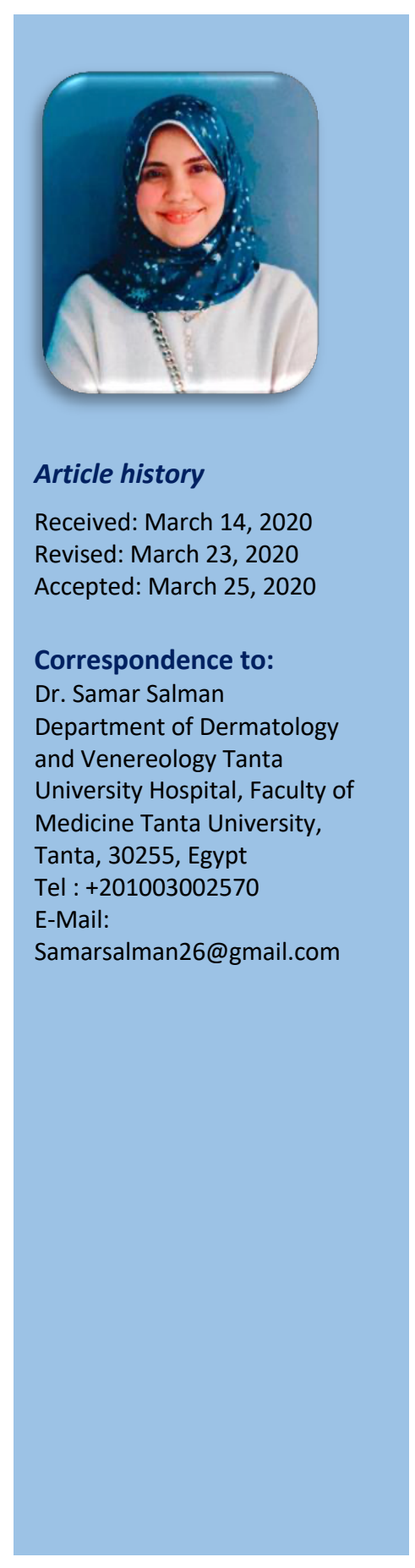




\section{REFERENCES}

1. Lu Q, Shi Y. Coronavirus disease (COVID- 19) and neonate: What neonatologist need to know. J Med Virol [Internet]. 2020 Mar 1;n/a(n/a). Available from: https://doi.org/10.1002/jmv.25740

2. Control D, Appendix S. C or $r$ e sp ondence SARS-CoV-2 Infection in Children. 2020;1- 3

3. Thappa D, Chiramel M. Evolving role of immunotherapy in the treatment of refractory warts. Indian Dermatol Online J [Internet]. 2016;7(5):364. Available from: http://www.idoj.in/text.asp?2016/7/5/36 4/190487

4. Salman S, Ahmed MS, Ibrahim AM, Mattar OM, El-Shirbiny $H$, Sarsik $S$, et al. Intralesional Immunotherapy for the Treatment of Warts: A Network Meta- analysis. J Am Acad Dermatol [Internet]. 2018 Oct 5; Available from: https://doi.org/10.1016/j.jaad.2018.07.00 3

5. Bermejo-Martin JF, Almansa R, Menendez R, Mendez R, Kelvin DJ, Torres A. Lymphopenic community acquired pneumonia as signature of severe COVID- 19 infection. The Journal of infection. England; 2020.

6. Baskar P V, Collins GD, Dorsey-Cooper BA, Pyle RS, Nagel JE, Dwyer D, et al. Serum antibodies to HIV-1 are produced post- measles virus infection: evidence for cross-reactivity with HLA. Clin Exp Immunol [Internet]. 1998 Feb;111(2):251- 6. Available from: https://pubmed.ncbi.nlm.nih.gov/948638 9

7. DongY,MoX,HuY,QiX,JiangF,JiangZ, et al. Epidemiological Characteristics of 2143 Pediatric Patients With 2019 Coronavirus Disease in China Epidemiology of COVID-19 Among Children in China. 2020

8. Steinglass R. Routine immunization: an essential but wobbly platform. Glob Heal Sci Pract [Internet]. 2013 Nov 14;1(3):295- 301. Available from: https://pubmed.ncbi.nlm.nih.gov/252765 44
9. Li Y, Guo F, Cao Y, Li L, Guo Y. Insight into COVID2019 for pediatricians. Pediatr Pulmonol [Internet]. 2020 Mar 18;n/a(n/a). Available from: https://doi.org/10.1002/ppul.24734

10. Arts RJW, Moorlag SJCFM, Novakovic B, Li Y, Wang $S-Y$, Oosting $M$, et al. BCG Vaccination Protects against Experimental Viral Infection in Humans through the Induction of Cytokines Associated with Trained Immunity. Cell Host Microbe. 2018 Jan;23(1):89-100.e5.

11. Mihai G. Netea MG, Joosten LAB, Latz E, Mills KHG, Natoli G, Stunnenberg HG, OM, ElShirbiny $H$, Sarsik $S$, et al. Intralesional Immunotherapy for the Treatment of Warts: A Network Meta- analysis. J Am Acad Dermatol [Internet]. 2018 Oct 5; Available from: https://doi.org/10.1016/j.jaad.2018.07.00 3

12. Irani Thevarajan I, Nguyen THO, Koutsakos M, Druce J, Caly L, an de Sandt CEV, Jia X, Nicholson S, Catton M, Cowie B, Tong SYC, Lewin SR, Kedzierska K. Breadth of concomitant immune responses prior to patient recovery: a case report of non-severe COVID-19. Nat Med 16 March 2020.

13. Wang Z, Wan $Y$, Qiu C, Quiñones-Parra, Sergio M, Zhu Z, Loh L, Tian D, Ren Y, Hu Y, Zhang X, Thomas PG, Inouye M, Doherty PC, Kedzierskar K. Recovery from severe H7N9 disease is associated with diverse response mechanisms dominated by CD8+ T cells. Nat Commun. 2015 6, 6833 .

14. Salaman S. and Salem ML. Routine childhood immunization may protect against COVID2019. Medical Hypothesis, 2020, 140, 109689. 


\section{Egyptian Association for Cancer Research (EACR)}

http://eacr.tanta.edu.eg/

EACR is an NGO society that was declared by the Ministry of Social Solidarity (Egypt) No. 1938 in 19/11/2014 based on the initiative of Prof. Mohamed Labib Salem, the current Chairman of EACR. EACR aims primarily to assist researchers, in particular young researchers in the field of cancer research through workshops, seminars and conferences. Its first international annual conference entitled "Anti-Cancer Drug Discovery" was successfully organized in April 2019 (http://acdd.tanta.edu.eg). Additionally, EACR aims to raise the awareness of the society about the importance of scientific research in the field of cancer research in prediction, early diagnosis and treatment of cancer. EACR is also keen to outreach the scientific community with periodicals and news on cancer research including peer-reviewed scientific journals for the publication of cutting-edge research. The official scientific journal of EACR is "International Journal of Cancer and biomedical Research (IJCBR: https://jcbr.journals.ekb.eg) was successfully issued in 2017 and has been sponsored by the Egyptian Knowledge Bank (EKB: www.ekb.eg).

\section{EACR Chairman,}

Prof. Mohamed Labib Salem, PhD

Professor of Immunology

Faculty of Science, Tanta Universiy, Egypt 


\section{Editor-in-Chief}

Mohamed Labib Salem, PhD

Tanta University, Egypt

\section{Managing Editor}

Nehal Elmashad, MD

Tanta University, Egypt

Nabil Mohy Eldin, PhD

Kafrelsheikh University, Egypt

Doaa Al-Ghareeb, PhD

Alexandria University, Egypt

Abdel-Aziz Zidan, PhD

Damanhour University, Egypt

Wesam Meshrif, PhD

Tanta University, Egypt

Rasha Eraky, MD

Tanta University, Egypt

\section{Associate Editor}

Hesham Tawfik

Tanta University, Egypt

Mostafa El-Sheekh

Tanta University, Egypt

Yousry Albolkiny, PhD

Tanta University, Egypt

Gamal Badr

Assuit University, Egypt

Elsayed Salim

Tanta University, Egypt

Essam Elshiekh

Tanta Cancer Center, Egypt

\section{Editorial Board}

\author{
Alberto Montero \\ Taussig Cancer Center, \\ Cleveland, USA \\ Marcela Diaz \\ Cleveland Clinic Foundation, USA \\ Yi Zhang \\ Zhengzhou University, China \\ Shengdian Wang \\ Chinese Academy of Sciences, \\ China \\ Faris Alenzi \\ Prince Sattam bin Abdulaziz \\ University, KSA \\ Mark Robunstein \\ Medical University of South \\ Carolina, USA \\ Mamdooh Ghoneum, DSc \\ Charles Drew University of \\ Medicine \& Science, USA
}

Natarajan Muthusamy, DVM

The Ohio State University, USA

Hideki Kasuya MD, PhD,

FACS

Nagoya University, Japan

Sherif El-Khamisy, MD

Sheffield University, UK

Mohamed Abou-El-Enein,

MD

Charité Universitätsmedizin

Berlin, Germany

Alaa Eldin Almostafa, MD

McGill University, Canada

Amr Amin

United Arab Emirates

University, UAE

AbdeIRahman Zekri

National Cancer Institute, Egypt

Mohamed Attia, MD

Tanta University, Egypt

Mohamed Elshanshory, MD

Tanta University, Egypt

Hussein Khamis

Alexandria University, Egypt

Magdy Mahfouz

Kafr Elsheikh University, Egypt

Ehab Elbedewey

Tanta University, Egypt

Abeer Badr

Cairo University, Egypt

Nadia Hamdy, PharmD

Ain Shams University, Egypt

Ibrahim El-Sayed

Menoufia University, Egypt

Tarek Aboul-Fadl, PharmD

Assiut University, Egypt

Mohamed Noureldin

Banaha University, Egypt

Haiam Abou Elela

National Institute of

Oceanography and Fisherie,

Egypt

Sameh Ali, MD

Nationa Liver Institute, Egypt

Maha EL-Demellawi

City for Scientific Research \&

Technology Applications, Egypt

Desouky A Abd-El-Haleem

City for Scientific Research \&

Technology Applications, Egypt
Ashraf Tabll

National Research Center, Egypt

Wael Lotfy, MD

Alexandria University, Egypt

Olfat Gadallah, MD

Tanta University, Egypt

Nahla Shoukry

Suez University, Egypt

Medhat Eldenary

Tanta University, Egypt

Nagla Sarhan, MD

Tanta University, Egypt

Naglaa Fathy, MD

Zagazik University, Egypt

Azza Hasan Mohamed Menufia University, Egypt

Nanees Gamal Eldin

Tanta University, Egypt

Mohamed Mansour, UK

Sabbah Hammoury

Alexandria Ayadi Almostaqbal

Oncology Hospital, Egypt

Nehal Aboulfotoh

Zewail City for Science and

Technology, Cairo, Egypt

Amir Elkhami

Galaxo, San Francisco, USA

Rabab Khairat

National Research Center,

Giza, Egypt

Ahmed Alzohairy

Zagazi University, Egypt

Wgady Khalil

National Research Center, Egypt

Sayed Bakry

Alazhar University, Egypt

Mohamed Ghanem, MD

Kafr Elshikh University, Egypt

Mohamed Salama, MD

Mansoura University, Egypt

Mona Marie, MD

Alexandria University, Egypt

\section{For more information, contact}

Hamdi Kandil

Tanta University, Egypt

Email: ljcbr100@gmail.com 